\title{
Sections News/Nouvelles des Sections
}

\section{OTTAWA VALLEY}

\section{Chairman's Report}

My first year as Chairman has gone by quickly. Your Council has been active on your behalf organizing and coordinating activities for the Section, providing advice and input to various groups, communicating with the national office, our members, and a variety of other organisations, and managing the finances of the Section.

Section Council members, with the assistance of many members at large, provided feedback to CIF Head Office on the new codes of practice and ethics. We also provided input to the National Executive, for their development of a short list of the 5 to 10 most important forestry issues requiring solutions at the national and regional level. This initiative was in response to the CIF Board decision at their meeting in September 1991 that as part of the action plan, the CIF should take a stronger leadership role on forestry issues in Canada. The CIF Ottawa Valley Section is submitting comments on the revisions to the Ontario Trees Act, the Mississippi Valley Conservation Authority Watershed Strategy, and to the Ontario Forest Policy Panel. The Council recently considered the need to develop a formal speakers Bureau for the section, and the interest in hosting a communications forum. I had the opportunity to sit in for Chris Lee when he was in China, to present the views of the CIF to the Ontario Environmental Assessment Board hearings when they passed through Ottawa.

This year, we have attempted to increase the visibility of the OVS by reporting on our activities consistently in the Forestry Chronicle. We will have placed four items, along with photos, throughout this year, so all CIF members can see what their colleagues in the Ottawa Valley Section are up to. The national office offered, in conjunction with their survey on the Chronicle, to have the sections circulate their own questionnaire, but as we did that not too long ago, we decided not to repeat this undertaking.

Again in 1992, the Section offered to sponsor a special award at the Ottawa Regional Science Fair, in mid-April at the Canadian Museum of Nature. Our Treasurer, Kathryn Buchanan, presented the CIF prize at the official awards ceremony, and we were pleased to have the winners from College Catholique Samuel Genest with us at our annual meeting, to present their trophies and see their exhibit.

At our meeting in December, we were fortunate to have National Vice President T. Rotherham with us for the presentation of plaques to two CIF fellows, Vidar Nordin and Cam Place. A Fellow is a member or ex-member who has made an outstanding contribution to the advancement of forestry or to the Institute, and is elected by the CIF national Board of Directors. Only 3 Fellows were elected in 1991, and two of them were from the Ottawa Valley Section. We again congratulate these gentlemen. At our last meeting we also had the pleasure of presenting the 1991 CIF Gold Medal for the University of Toronto to Mr. Andrew Dunlop.

In late February, the Section Council agreed to send a letter of support to the Eastern Ontario Model Forest Proposal of the Eastern Ontario Forest Resources Stewardship Council. It was recently announced that their proposal had been accepted. We congratulate Dr. Ross Silversides, and Council member Brian Barkeley, for this achievement. I under- stand that the Ottawa Valley Section will get an opportunity to attend a meeting on this project, and be invited to participate in future activity.

I believe that the Ottawa Valley Section has a unique membership, with a strong segment of the leadership in Canadian Forestry within our Section boundaries. We have a great deal of experience to draw upon, including several former CIF Executive Directors. With the Institute's national office here, we are fortunate to be able to see Chris Lee often, and be well informed of CIF national activities. We congratulate Chris and the National Executive for their achievements and dedication to the forestry profession.

Before he left us for Rome, Nominations Committee Chairman Claude Leger put together a strong Section Council to work on the members' behalf. You have a talented and enthusiastic group, and I have enjoyed working with them. Within the Council we have Federal and Provincial government employees, consultants, and association executives with wide and varied areas of interest and specialisation. Each has indicated a willingness to continue to serve, and we look forward to next year.

Richard Lipman Chairman, Ottawa Valley Section

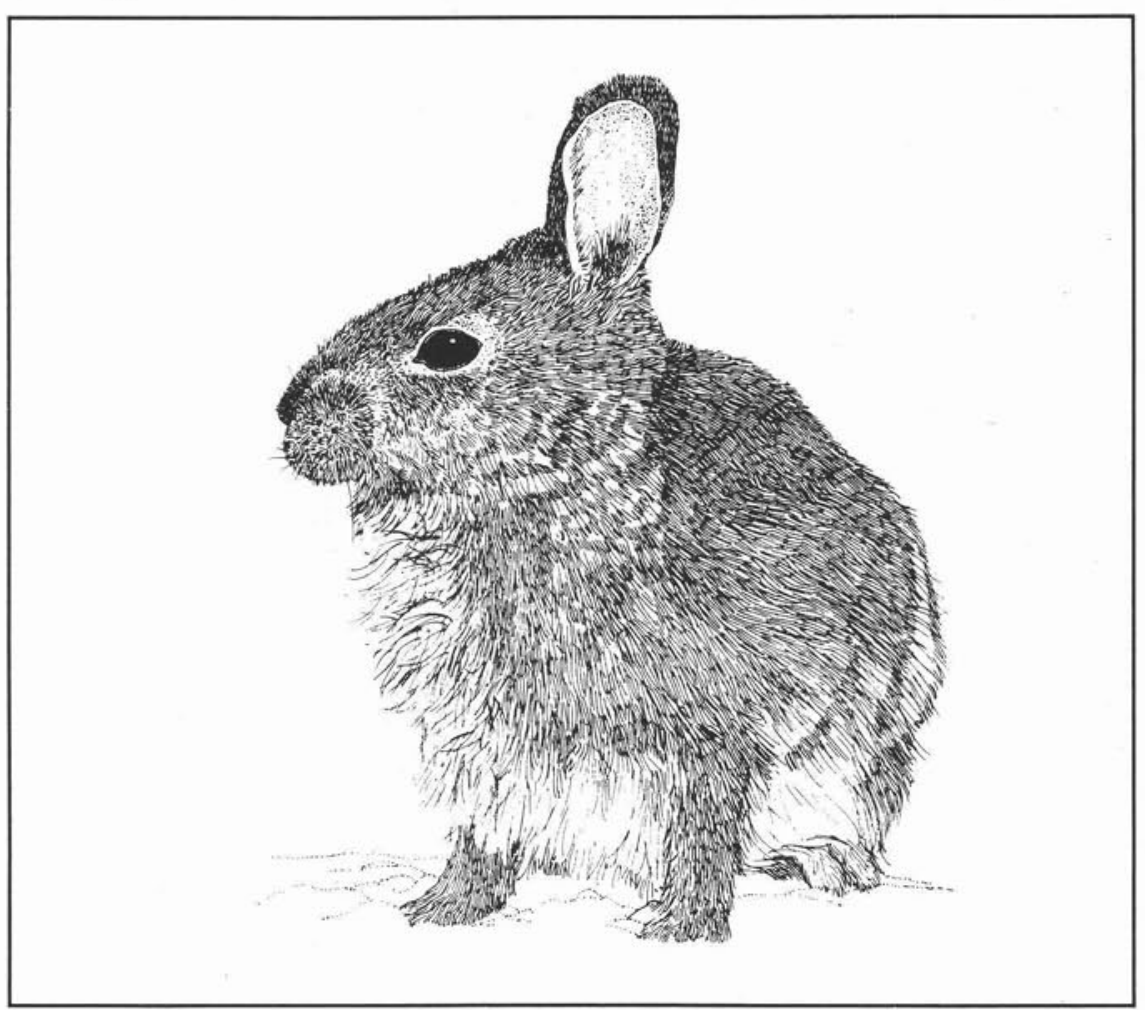

